\title{
An Investigation of Five Japanese English Teachers' Reflections on Their U.S. MA TESOL Practicum Experience
}

\author{
Sandra McKay
}

San Francisco State University

This study examines the practicum experience of five Japanese English teachers pursuing a master's degree in TESOL at a U.S. university. Drawing on data gathered from individual and group interviews, mentor teacher and author field notes, student teaching logs and final reports, the author examines five Japanese graduate students' reflections on their practicum experience. The data suggests that whereas the students clearly faced some common challenges, their personalities and English learning and teaching backgrounds as well as their specific teaching context influenced their particular teaching concerns. Although much of the data highlights the special problems that nonnative English speakers face in teaching in an ESL context, the paper notes the benefits such an experience can afford and suggests ways of modifying the TESOL practicum experience so that it is more beneficial to teacher trainees.

本論文では、アメリカの大学院英語教育学修士コースに在籍する日本人英語教員 5 名の 英語教育実習を考察した研究を報告する。個別及びグループ・インタビュー、指導教員及 び筆者のフィールド・ノート、大学院生の授業ノート及び最終レポートからさまざまな データを収集し、自己の英語教育実習について、5名の大学院生がどのような考えをもっ ているのかを考察した。これらのデータから、5名の院生は全員が共通の問題に直面して いたが、それぞれが抱えていた教育上の関心事は、それぞれの人柄、英語教育歴、学習 歴、授業環境に影響され異なっていることが明らかになった。得られたデータの多くは、 英語を母語としない英語担当教貝が直面する問題点を示したのだが、同時に本研究は、こ のような実習がもたらす意味を確認し、教員眼成者にとって教育実習がより有益なものに なるよう、教育実習のあり方を検討する方法を示した。

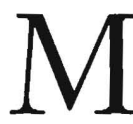

any ESOL educators assume that there are considerable benefits in prospective Japanese English teachers obtaining an advanced degree in an English-speaking environment. They maintain that because students have to use English consistently in their graduate program and daily life, they have many opportunities to increase their communicative competence in English. In addition, some contend that 
studying abroad introduces students to the latest and so-called most progressive methods being developed in English-speaking countries. Yet these students face particular challenges in terms of completing their degree and ultimately in entering or re-entering the English teaching profession in Japan. Cultural differences in classroom expectations can exist between Japan and the host country; overseas professors may not be familiar with the English teaching context of Japan and hence not examine the appropriateness of particular teaching approaches and strategies for the Japanese classroom; finally, much of the research and many of the teaching materials introduced in the graduate program may be generated in and for an English as a Second Language (ESL) situation and not be appropriate for the English as a Foreign Language (EFL) setting in Japan.

Although recent attention has been given to examining the nonnative English speaker as English teacher (Liu, 1999; Medgyes, 1992, 1994), little research has been done regarding the preparation of these teachers, specifically in an English-speaking environment. The purpose of this paper is to contribute to an understanding of the teacher preparation of nonnative English speakers by examining the teaching reflections of five Japanese teacher trainees regarding their teaching practicum. As a forum for combining theory and practice, the teaching practicum provides an ideal context in which to examine the special challenges and opportunities that exist for Japanese English teachers studying abroad. Drawing on data gathered over a six-month period, I examine the reflections of these teachers and argue that whereas all five students shared particular concerns arising from what they perceived as their lack of knowledge of English and of U.S. culture, various individual factors such as previous teaching experience, English language proficiency, and personality, as well as contextual factors such as the language proficiency of the students and the philosophy of the mentor teacher influenced how each teacher trainee assessed his/her teaching experience in an ESL context.

To begin, the paper considers the role of the practicum in MA TESOL programs.

\section{The Practicum in MA TESOL Programs}

The practicum is a common feature of MA TESOL programs. In fact, Palmer (1995) in his survey of graduate programs listed in the Directory of Professional Preparation Programs in the United States, 1992-1994 (Kornblum, 1992) notes that two thirds of the programs responding to his survey required a practicum or internship course. Given their widespread implementation, it is surprising how little research exists on the 
practices or efficacy of practicums. The most thorough investigation of the practicum is Richards and Crookes (1988), who surveyed 120 programs in the United States having courses leading to some type of concentration or specialization in teaching English as a second/foreign language.

According to their survey, most practicum experiences occur at the end of the degree program, are compulsory, and involve approximately three units of credit. The curriculum in most of these courses involves indirect experiences (i.e., observations of experienced teachers, viewing of videotapes of sample lessons, or observations of peers) and direct experiences (i.e., teaching in actual classrooms, teaching peers, or teaching classes specifically designed for practice teaching). Of these possible practicum experiences, supervised classroom teaching in real classrooms is allotted more time than any other component. Based on their survey, Richards and Crookes conclude that whereas the importance of the practicum experience is widely recognized, a great variety of different approaches is being implemented in ESOL teacher preparation courses. ${ }^{1}$ Furthermore, little information exists on the effectiveness of current practicum experiences. ${ }^{2}$

\section{Reflective Teaching}

Currently in many practicum experiences, teacher trainees are encouraged to monitor their teaching through personal reflections recorded in diaries or journals (see, e.g., Stoynoff, 1999; Valli, 1992). As Richards (1990) points out, "Reflection is acknowledged to be a key component of many models of teacher development. The skills of self-inquiry and critical thinking are seen as central for continued professional growth" (p. 119). The goal of such reflection is to promote a view of the teacher as researcher. Wallace (1996), for example, argues that teacher trainees should be involved in structured reflection so that "they can become their own researcher" (p.281). Stanley (1998), in her discussion of teacher reflection, sets forth a framework for teacher reflectivity. She contends that reflective teaching involves a series of phases that involves engaging with reflection, thinking reflectively, using reflection, sustaining reflection, and ultimately practicing reflection. The final phase, practicing reflection, requires teachers to actually apply the insights they have gained through reflection to their own teaching context.

The teacher education program with which I am involved has encouraged reflective teaching through the use of teaching logs. Teacher trainees are required to keep a teaching log throughout their semester of teaching. In the written instructions they receive at the beginning of the 
semester, they are told:

The log that you are being asked to keep . . . is a means for you to reflect on your experiences and observations as you work as a student teacher in an ESL class this semester. . . It is an opportunity for you to raise questions, to ponder why an activity seemed to work or not work, to wonder whether there might be some other way to accomplish a comparable goal, to reflect on impressions or surprises or feelings, to react to the students' needs, interest, or behavior, to see connections between what you have learned throughout your study in the MA program and your ESL classroom experiences, to note what impressed you, what you learned, what you found clever or noteworthy, to discuss your struggles and successes.

Teacher trainees are also encouraged to reflect on their teaching experience in a final report in which they consider how they have developed as teachers during the semester and how they hope to continue to grow. In addition, teacher trainees are involved in individual and group conferences in which they critically discuss their teaching experiences. The goal of the present investigation is to examine the teaching reflections of five Japanese teacher trainees, as expressed in their teaching logs, final report, and conferences, as a way of gaining insights into the particular concerns of nonnative speakers teaching in an ESL context.

\section{The Target Practicum Context}

The practicum experience for these five Japanese teacher trainees consisted of a three-unit ungraded course taken in their last semester of study for their MA TESOL degree. The teacher trainees had already completed prerequisite courses in pyscholinguistics, sociolinguistics, and language structure, as well as 12 graduate units of core courses focusing on methods and material development and 12 units of elective courses. Teacher trainees were encouraged to select their own practicum teaching context based on classroom observations they had been involved in throughout the program. The rationale for such an approach to practicum placement was that teacher trainees would be able to select a teaching context and a mentor teacher they believed would be most beneficial to their continued professional growth. In reality, many teacher trainees, like those considered in Richards and Crookes' (1988) investigation of the teaching practicum, selected their practicum context based on such factors as personal contact with and reputation of the mentor teacher, proximity of the school to their home, and recommendations of other teacher trainees in the program. Many of the five teacher trainees se- 
lected their practicum experience based on their work with the mentor teacher in earlier semesters or on the recommendations of other teacher trainees in the program, often other nonnative speakers.

\section{Method}

\section{Data}

During the fall semester of 1998 I supervised five Japanese teacher trainees enrolled in their teaching practicum for a MA TESOL degree. The teacher trainees taught in a variety of ESL teaching contexts ranging from a beginning level spoken English class offered at a local community college to an advanced grammar course given at a four-year university. All five teacher trainees volunteered to be part of a project that explored the concerns of nonnative speakers of English teaching in ESL contexts and agreed to write regular journal entries throughout the semester. They also agreed to participate in individual and group interviews in which they elaborated on issues raised in their journals. In addition, they completed an extensive English language learning and teaching background questionnaire at the beginning of the semester and wrote a final report on their teaching experience at the end of the semester. I observed their classes during the semester, noting possible teaching moments in which being a nonnative speaker of English was a central factor. Such instances were then discussed in post-lesson interviews.

Three of the mentor teachers (i.e., the teachers in whose classes the teacher trainees taught) gave me logs in which they recorded specific teaching moments that seemed influenced by the fact that the teacher trainees were nonnative speakers of English. Because the mentor teachers did this voluntarily and over and above their regular work with the teacher trainees, there was no consistency to the length or frequency of these logs. I examined all of the data in a recursive fashion, highlighting and coding particular themes by type of document (i.e., students' teaching logs, students' language and teaching background questionnaire, students' final report, the mentor teachers' logs, and my field notes) and by the individual teacher trainee involved. The Findings section below discusses the prevalent themes evident in the data analysis and provides the source for the data included.

\section{The Participants}

The five teacher trainees differed in their exposure to English both in Japan and the U.S. as well as in their previous English teaching experience. The following is a brief description of the teacher trainees. ${ }^{3}$ 


\section{Hideki:}

Like most Japanese, Hideki began learning English in junior high school. He continued studying English in college but, as he says in his background questionnaire, he "hated to study English." He first traveled to the U.S. when he was 20 years old for a one-month vacation, which motivated him to take much more of an interest in English. He subsequently spent several vacations in the U.S., and when he was 22 studied English for a year in the U.S. He had no teaching experience prior to coming to study in the U.S. For his practicum he chose to work in a survival English class at a vocational school with a class of six students, all Russian speakers with almost no previous knowledge of English.

\section{Sachiko}

Sachiko began studying English at a small private Catholic school when she was in elementary school. She attended a Catholic junior and senior high school and college where she received a good deal of instruction in English. She first traveled to an English-speaking country when she was 19 for a one-month homestay in Canada and then spent one month in New Zealand the following summer. In Japan she had a lot of teaching experience, working at a junior high school for five years. For her practicum, she worked at a community college in an adult evening integrated skills class for high beginning level students. The class had close to 30 students, many of them older students, mainly from Asian and Pacific Rim Countries.

\section{Koji}

Koji started studying English at the age of six at a private English conversation school that used drama to develop oral skills. When he was seven he went to Portland, Oregon with his family and stayed there for two and a half years because of his father's job. There he attended a public elementary school in the regular classroom with native speakers with an ESL class for one hour a day. In fourth grade he returned to Japan and again enrolled in the English conversation school. Other than the time in Portland, he did no traveling or living in an English-speaking country and had no prior teaching experience in Japan. For his practicum he taught at the same school as Sachiko but in a lower level proficiency class.

\section{Sadayuki}

Sadayuki first started studying English in junior high and continued to study English at the university, taking various kinds of English classes. He first traveled to an English-speaking country at the age of 21 for a 
two-week English course in Orlando, Florida. He had no prior teaching experience in Japan though he had recently passed the exam for his teaching credential and had a job waiting for him at a Japanese high school. His teaching practicum was in a credit-bearing reading course for nonnative speakers at a community college. The class had $25 \mathrm{col}-$ lege-age students, mainly from Asian and Pacific Rim countries.

\section{Mariko}

Mariko began studying English in junior high school and majored in English literature at the university. Her only exposure to an Englishspeaking environment was when she was 27 and took a summer course at San Diego State University. Like Sachiko she had five years teaching experience, teaching in a junior and senior high school. For her practicum, she worked in a credit-bearing grammar review class for nonnative speakers at a public university. The class had 22 college-age students, mainly from Asian and Pacific Rim countries.

Table 1 provides a summary of the English language learning and teaching experience of the graduate teacher trainees.

Table 1: Language and Teaching Background of Teacher Trainees

\begin{tabular}{|c|c|c|c|c|c|}
\hline Name & Gender & Age & $\begin{array}{l}\text { First Exposure } \\
\text { to English }\end{array}$ & $\begin{array}{l}\text { Time in U.S. } \\
\text { at Start of MA }\end{array}$ & $\begin{array}{l}\text { Years of English } \\
\text { English Teaching }\end{array}$ \\
\hline Hideki & M & 30 & Junior High & $11 / 2 \mathrm{yrs}$ & none \\
\hline Sachiko & $\mathrm{F}$ & 30 & $\begin{array}{l}\text { Elementary } \\
\text { School }\end{array}$ & 2 months & $\begin{array}{l}5 \text { years, } \\
\text { Jr. high }\end{array}$ \\
\hline Koji & M & 27 & $\begin{array}{l}\text { Elementary } \\
\text { School }\end{array}$ & $21 / 2$ years & none \\
\hline Sadayuki & M & 21 & Junior High & 2 weeks & none \\
\hline Mariko & $\mathrm{F}$ & 35 & Junior High & 4 weeks & $\begin{array}{l}5 \text { years, } \\
\text { Jr. \& Sr. high }\end{array}$ \\
\hline
\end{tabular}

\section{Results}

\section{Common Concerns}

Though the five teacher trainees differed greatly in their English learning and teaching experience and in their particular teaching contexts, they shared common concerns that were apparent in many of their teaching journals, individual conferences, and group interview. These centered around their lack of knowledge of English, particularly in their knowl- 
edge of U.S. culture, and their uncertainty as to what method or methods to use in both the U.S. and Japan. Whereas native English-speaking teacher trainees may also experience a lack of knowledge and an uncertainty as to methodology, these five teacher trainees' awareness that English was not their mother tongue, coupled with their own English learning experience in Japan, made these concerns very salient in their teaching logs. Clearly, more research is needed to determine to what extent the concerns raised by the teacher trainees are shared by native English-speaking teacher trainees and to what degree the fact of being nonnative English speakers, trained in educational contexts that promote teaching methodologies different from those emphasized in a U.S. context, can heighten teacher trainees' awareness of their lack of knowledge and their uncertainty as to appropriate methods.

\section{Personal Knowledge}

In his examination of nonnative English speakers, Medgyes (1992) contends that the main element that hampers nonnative English speakers' effectiveness as teachers is "a state of constant stress and insecurity caused by inadequate knowledge of the language they are paid to teach" (p. 348). This stress and insecurity was evident in the experience of the teacher trainees, whose confidence in English was challenged both by their students' perception of them and their own unfamiliarity with aspects of U.S. culture. In their teaching logs, several of the teacher trainees reflected on instances of when they doubted their own competency in English and feared they were giving students incorrect information. Mariko, for example, wrote in her $\log ,{ }^{4}$

Some of the students asked me about grammar and I tried to answer. Whenever I did not have confidence about my answers, I always asked questions to my master teacher, because what I was afraid the most was to give them wrong information. (TL 3, page 4, 12-7-98)

The teacher trainees' personal lack of self-confidence was heightened when their students challenged the accuracy of their knowledge. Sadayuki, for example, recounted the following experience.

During the group work while I was circulating the class, one student asked me if the word she wrote was correct or not. I told her that was OK. But she also asked my mentor teacher to make sure if what I suggested was right or not. The same student said a main idea of a paragraph comes at the beginning. In class, I told Ss that a main idea of a paragraph can come to the end of the paragraph sometime. After the class, I happened to eavesdrop that the student was asking my mentor teacher to make sure. (TL 2, page 4, 11-6-98)

In the group interview I tried to clarify with the teacher trainees whether 
or not they felt this challenge was due to the fact they were nonnative English speakers or to the fact they were teacher trainees. ${ }^{5}$

Author: Do you think they do that because you are, you are beginning teachers or do you think they do that because they think, "Ummm, this person is teaching a second language, so, he may not know."

Sadayuki: Yeah ... I first assume that you know, because I I am a nonnative teach, English teacher, so you know, maybe somehow, I I assumed, somehow those students thinks me as, you know, the same learner, so you know, not so trustworthy as the teacher, real, you know, native speaking teacher. (GI, page 3, 11-19-98)

Unfortunately, the teacher trainees themselves seemed to share the common attitude that it was only native speakers of English who could be the "real" teachers of English.

The area in which the teachers seemed to experience the greatest sense of a lack of knowledge was in the area of cultural knowledge. Over and over again the five teacher trainees recounted experiences of when they lacked the necessary cultural background to teach in an ESL context. Hideki, for example, described how his lack of knowledge in getting a job in the U.S. influenced his effectiveness in teaching a survival English unit on finding employment:

When I was asked by my master teacher to give a lesson which relates to job searching skill, I worried whether I teach it or not. Teaching job searching skill is different from teaching grammar rules. First of all, teaching job searching skill requires both knowledge and experience. Unfortunately, I am foreign student and I can't work in the U.S. Therefore, I don't have enough knowledge about how to get a job. Filling out application form and writing resume are totally different from Japanese way. I didn't know how to fill out application form and what need to write in resume. For example, in Japan, when we apply for jobs, we hardly use application form. We call, make an appointment and bring resume. This is general procedure of applying jobs in Japan. But in here, people walk in companies (stores) and ask application form. The students are serious about finding jobs, so I couldn't give different information or skip this kind of information. (TL 3, page 1-2, 12-4-98)

Not only did Hideki's lack of knowledge entail unfamiliarity with how to go about getting a job, but he also was uncertain as to specialized vocabulary involved in finding a job in the U.S. For example, he pointed out that many job advertisements contain abbreviations that he did not know.

For example, I didn't know the meaning " $401 \mathrm{k}$ " (I'm not sure, $401 \mathrm{k}$ ?).

" $\mathrm{K}$ " means kilo (thousand), so when an advertisement indicates 
information about money, sometimes " $k$ " is used. But 401k doesn't mean about money. It means benefit. It is difficult for me to know all meanings of abbreviations. (TL 3, page 2, 12-4-98)

Sachiko described a similar experience of not knowing the meaning of a term in a U.S. context.

The other day I had to teach new vocabulary. Some of them was a bus station, a day-care center, a clinic, a hospital, a police station, and an employment office. In order to teach new vocabulary without a translation, I thought I had to describe what people were doing in these places. Then, I realized. The places I had never been were impossible to describe. Even if I know those places in Japan, what people are doing could be different in this country. For example, I had never been to a day-care center, clinic, police station, and an employment office in this country. First of all, I did not understand the difference between a day-care center and a nursery school, a clinic and a hospital. Both of them are translated into the same word in Japanese. (TL 1, page 3, 10-1-98)

Sachiko's lack of knowledge about aspects of U.S. society was heightened by the fact that in some instances her students, far less proficient than she in English, had this knowledge because they had lived in the U.S. for a considerable length of time. It is interesting to note that both Hideki and Sachiko viewed the role of the teacher as the "knower," who is supposed to be able to supply a correct answer to their students' questions, even though in their methods courses they had been introduced to the concept of the teacher as facilitator who encourages students to assume the role of the knower in supplying needed information. It is possible that Hideki and Sachiko, though aware of alternative roles of teachers and learners, were operating under assumptions about the role of a teacher promoted in their classroom learning in Japan. ${ }^{6}$

On the other hand, as nonnative English speakers, the five teacher trainees did have particular personal knowledge that was valued in their ESL teaching context. For one thing, the teacher trainees' knowledge of Japanese culture made them more aware of cross cultural differences. Sachiko, for example, described an instance when students in her class were asked to talk about their jobs. However, she was concerned that students may not want to talk about their jobs, especially if they were not proud of their job in the U.S. She noted that in Japan asking people about their jobs is not considered polite, especially in a public context like a classroom. She believed this knowledge provided her with an advantage over many native English speakers.

As a non-native speaker, I am glad that I can have a different perspective from native speakers. For example, I know that at least in Japan teacher 
should not require Ss to talk about their jobs in public. I know it is not an appropriate topic in Japan. Many native speakers who have not lived in the countries where they teach English as a foreign language do not realize it for a long time. That is why I was concerned with the topic from the beginning. (TL 2, page 2, 11-6-98)

Although Sachiko was aware of the possible negative feelings students may have regarding the topic of jobs, she was unsure as to whether or not this topic should then be used in an ESL context.

However, in case of teaching in an ESL setting, I am not sure if the topic is totally acceptable or not in this country. Moreover, I do not know if I should adjust American ways or respect Ss' culture and should avoid these things as a teacher. (TL 2, page 2, 11-6-98)

Another area in which the teacher trainees generally felt they had an advantage over native speakers is one pointed out by Medgyes (1992), namely that nonnative speakers can serve as models of successful learners, sharing with their students their own English learning strategies. This topic was discussed in the group interview when I asked them about what advantages they felt they had as nonnative speakers of English.

Sadayuki: Ummmm, maybe as a model of learner. Second language learner. Yeah, something like that ... I can I can tell students my strategy to read, and to write, and that stuff.

Author: Yeah. Do you do that?

Sadayuki: I, today I just talked about little bit about you know how to read. How to, you know, approach to the reading. Something like, you know, "Okay, first just ... just first try to get the main idea," something like those directions. And next you know if you come up with the unfamiliar word, and you think that word has the kind of key meaning and still you're not sure, just look up the dictionary or something like that. Those I . . I use that kind of strategy throughout years and years so. (GI, page 5, 11-19-98)

Such examples show that although the teacher trainees' knowledge was consistently challenged in their ESL teaching experience, there were instances when the teacher trainees experienced the benefits of being a nonnative speaker.

\section{Teacher-centered Versus Student-centered Classrooms}

The issue of personal knowledge was not the only common factor to these five teacher trainees' ESL teaching experience. All of them struggled with the question of what method or methods to implement in their classrooms, both in the U.S. and once they returned to Japan. This struggle was heightened by the fact that, whereas they had experienced 
largely a teacher-centered classroom in their English classes in Japan, in the U.S. the advantages of a student-centered classroom was emphasized in many of their graduate methodology courses and implemented in their classrooms. Sadayuki pointed out that perhaps he was too concerned about implementing a student-centered classroom because of his own experience in Japan and the U.S.

One thing I realized was that I might be too conscious about studentcentered instruction (not teacher-centered) because of my educational background. Since I went through the teacher-centered instruction including deductive explanations when I was a junior high and high school student, and since I experienced a lot of student-centered activities in MATESOL program and gained a sort of bad images about teacher-centered classrooms, I may be more concerned about Ss involved and participating activities than native speakers of English. I came up with this idea because my mentor teacher does sometimes a teacher-centered talk, which is fun. But what I have done so far is more Ss-controlled group work activities. (TL 2, pages 4-5, 11-6-98)

Koji noted a similar experience when his own aversion to an emphasis on accuracy that he experienced in his English classes in Japan led him to believe that such an emphasis should be avoided. Yet he was unsure as to whether or not an emphasis on accuracy was appropriate in his beginning level ESL teaching context.

I didn't like accuracy over fluency in Japanese English classes. Too much grammar instruction made me bored in English classes. When I saw my mentor teacher doing similar things (i.e., emphasizing to capitalize the first letter in a sentence and person's name again and again, to write a period at the end of a sentence, and so on), I almost automatically thought that the students must have been bored. I thought the teacher should have de-emphasized teaching details. I thought like this by transferring my experience and it was not easy to ignore my memory. But the need of the immigrated students in U.S. could be different from that of Japanese people in Japan. The adults who were looking for a job need accuracy (i.e., capitalizing the first letter in a sentence and person's name, writing a period at the end of a sentence, etc.) according to a job. (TL 2, page 5, 11-6-98)

Hence the teacher trainees, influenced by their own Japanese language learning experience and their graduate education, were constantly struggling with the question of what goals and methodology were best for which context. By and large, however, perhaps due to the emphasis on communicative language teaching in their graduate program, they were convinced that a more student-centered classroom should be implemented, both in the U.S. and Japanese context. They were, however, quite aware that implementing a student-centered classroom in a Japa- 
nese context may be difficult because many Japanese students and teachers expect a teacher-centered classroom that focuses largely on preparation for the university entrance exam. In the group interview, I raised the question of how they hoped to implement a student-centered classroom once they returned to Japan in light of the fact that many of their teaching colleagues and students may not support such an approach and that as young teachers they may not be in a position to implement such change.

Author: I mean, do you think, I mean, you are gonna go back with this idea, "I've got to do group work, I've got to do communicative language teaching," and all of the sudden, there maybe, "Uh-uh, not here." Sachiko, you say yes, why?

Sachiko: Yeah, we often talk about it, maybe when we go back to Japan, most of them, most of the teachers are older than us, and they, they are doing a very very traditional way of teaching, and then if we talk about CLT or new way of teaching English they will think, we are so naughty.

Author: Uh-huh.

Sachiko: Yeah.

Author: And what do you think your response to that would be?

Sachiko: We think we will be quiet for three years.

All: (Laughter)

Sadayuki: For first like 5,5 years, 5 years?

Sachiko: Yeah.

Sadayuki: I will be quiet, I I personally I will be quiet.

Sachiko: Me, too.

Sadayuki: You know for, after five years, I may be get promoted to, you know, curriculum designer or something like, you know, the academic year, supervisor or something. You know, when I when I get into that position, okay, that's the time to for me to speak up, about all, you know, ideas here. That's just social context, you know, social constraints. (GI, page 8, 11-19-98)

The shared laughter of this moment highlighted the fact that the teacher trainees realized the conflicts and problems they might encounter when they returned to Japan with an educational experience that in many ways had been very different from what they previously experienced at home.

\section{Individual Concerns}

Although most of the teacher trainees shared the challenges described above, their teaching logs and reports made it clear that each of the teacher trainees seemed to have a central concern about his/her teach- 
ing. In several instances, this overriding concern of their teaching reflections would not likely be predicted from looking at their previous English learning and teaching experience, as is evident in the discussion that follows.

\section{Mariko: "I always became nervous."}

Mariko had had more teaching experience than any of the other focus teacher trainees. Not only had she taught for five years in Japanese public junior and senior high schools, she had taught part time for two years in a juku ("cram" school for exam preparation). In light of her teaching experience, one might have assumed she would have had the most confidence in teaching English. However, her lack of confidence in her English competency, coupled with the fact that her practicum class was composed of very advanced ESL students, served to undermine the value of her previous teaching experience. In assessing her own strengths and weaknesses in English she wrote:

My greatest weakness is lack of confidence about my English competence. I have to use English when I teach English or communicate with students. I'm always afraid I would give them wrong information (answer). It is easy for me to explain grammatical rules in Japanese, but it is sometimes hard in English. I can explain if the sentence is grammatically correct or not, but I can not say if that is natural or not for native speakers. I'm also confused about some rules, such as articles, prepositions, countable uncountable nouns, because these are also my weakness in grammar. I try to check about these to my master teacher. I sometimes feel inferiority about my English ability. (BQ, page 4, 9-29-98)

She continued by describing the stress this situation caused her:

It is really challenging for me to teach university level students in English. I'm always afraid that I make error when I teach. I feel stress about my English ability. (BQ, page 4, 9-29-98)

In response to this situation, Mariko recounted over and over again both in our post-teaching interviews and in her teaching logs how nervous she felt about teaching in the U.S.

In her first teaching log, she noted that her nervousness made her make more grammatical errors than she normally would have. This nervousness was in sharp contrast to her teaching experience in Japan.

When I had taught in Japan, I rarely became nervous in the class. However, I always became nervous and felt some stress. At first a simple thing like calling roll made me feel uncomfortable because I could not pronounce the student's name correctly and took much longer time to remember the student's names. Sometimes I felt that it was 
hard to keep confidence as a teacher in the ESL class. I made a lot of grammatical errors and took longer time to answer a student's question.

(TL1, page 3, 10-2-98)

Perhaps it was because of Mariko's lack of confidence that her mentor teacher felt that some students were reluctant to seek her help. In her log, her mentor teacher noted:

In talking to the students as they come to see me, I get the sense some of them are a little reluctant to go to her for help. She would often volunteer to help them or I'd tell them to ask her and when I directly told them, they would go, but I have the feeling they were a little reluctant to ask her for help perhaps because she's a nonnative speaker and they weren't sure how much help they would get. (ML, page 1, 12-1-98)

Unfortunately, this nervousness and lack of confidence continued throughout the semester of teaching. Even in her final report Mariko noted her nervousness in teaching.

Teaching in Japan was much easier. When I taught in Japan, I gave directions to the students in Japanese or simple English. I did not have problems. However, when I taught an ESL class in English, I was very nervous and had trouble giving directions. (FR, page 1, 12-11-98)

In contrast to Mariko's consistent reflection on her own inadequacies and nervousness, my post-lesson interview notes described a much different situation. In the first interview, I noted the following.

Mariko tackled a difficult topic in her advanced grammar class-count and noncount nouns. I was impressed by her poise and self-confidence in the class. ... In our post-lesson discussion we talked about the differences she saw in teaching in Japan and the U.S. She said she appreciated not having to deal with discipline problems in her present class since this was an issue in Japan. However, she pointed out that she worried about knowing the grammar thoroughly enough to answer her students' questions. (FN, page 1, 9-28-98)

Hence, although I saw few signs of Mariko's nervousness in class, it was clear from her written reflections and her discussions with me, that her nervousness was a primary factor in her ESL teaching experience. Her lack of confidence and nervousness may have been heightened by her placement in an advanced college level grammar class in which she, like Hideki and Sachiko, assumed that the teacher must be the knower and hence be able to answer all of the students' grammar questions right away.

Sachiko: "I just don't know."

Like Mariko, Sachiko had had a good deal of teaching experience before coming to study in the U.S. However, unlike Mariko, she completed her practicum in a beginning level evening adult ESL program. 
Most of her students were older immigrants who were working full time and attending the evening class after work. Because many of her students had lived in the U.S. far longer than she had, she expressed a consistent lack of knowledge regarding life in the U.S. and the English needs of the students. In her first teaching log she recounted how she called a friend who was a native English speaker to find out the meaning of several terms that were in the lesson she was supposed to teach.

I called my friend who was a native speaker and asked those questions above. He told me the difference between the day-care center and nursery school, the difference between the clinic and hospital, and what people were doing in an employment office. I said people often asked directions at a police box in Japan, and asked if it was the same in case of the police station here. He said there were no police boxes here. "People do not ask directions in the police station," he said. I was very surprised and remembered that I had never seen police boxes here. I asked him just for in case, if people would pay money after meeting doctors at hospital because I was thinking to describe what people were supposed to do at a hospital. My original ideas were waiting for a doctor, meeting a doctor, and paying money. But he said people sometimes did not pay if their insurance covered. I was surprised. I told him that teaching ESL made me realize how much I did not know about the life here. I thought when I was teaching English in Japan, I was talking about a hospital in Japan, for example, not a hospital in this country in spite of the fact that I was teaching English, not Japanese. I said to him, "I wish I were a native speaker." I have lived here for two years, but I still have so much that I do not know about a daily life here. (TL1, page 4, 10-1-98)

She ended her log on a rather depressing note, again recounting how much she did not know.

If my students were thinking to study abroad, there might be something that I could be helpful for them, I think, because in that case I would be able to use some of my knowledge about the other countries and linguistic knowledge about English. However, the people I am meeting every night are studying English to have a better life here. I have lived here only for two years. I do not know how to call for a job interview, how to write a job application form, and how to be successful in a job interview though they are going to be taught in following weeks. I have never worked here, so I do not know how people are interacting in a working place. I guess the students know better than I because most of them are working. I do not know how to look for housing very well, I do not know how people buy houses. I cannot be helpful very much for them, I think. I do not know both English and skills which they want to know in order to live here. 
What I wrote sounds very negative and depressing, but I enjoy going to the class very much every night. (TL1, page 5, 10-1-98)

In her final report for the semester, Sachiko wrote that because of her lack of knowledge regarding life in the U.S. as well as her lack of awareness of the needs of her students, she had not done a very effective job teaching.

Compared with my own teaching in Japan, I think my teaching here is very shameful. I am even ashamed saying that I have a five-year teaching experience in Japan because of the fact that I myself know I am not doing well here. . . . If I would stay in this country and teach English, I think I need to improve everything. First of all, I should not be so nervous. I should know the students' proficiency level as well as their needs so that I could make lessons which have an appropriate level of difficulty and also meet their needs. I should be able to speak clearly and slowly, choosing the vocabulary the students can understand. I think the main reason why I could not do as well as I did in Japan was that I did not know almost anything about the students. (FR, page 3, 12-11-98)

In our post-lesson interviews, Sachiko consistently referred to the struggle she was having both with teaching adults as opposed to young people and with her lack of knowledge about her students' needs and their life in the U.S. In my interview notes after my last observation of her teaching, I wrote,

Sachiko questioned her choice of topic for the class (recipes). She said she was struggling with what topic would be sophisticated enough for adults but not too difficult in terms of language. She mentioned that she (and the master teacher) had little sense of when these adults actually used English. She was surprised that students hadn't been asked this. She emphasized how much harder it was here to teach adults rather than junior and senior high students in Japan. She said this again was due to choosing a mature topic and dealing with it in simple language. (FN, page 1, 11-4-98)

Although Sachiko believed that her lack of knowledge of U.S. culture and of the needs of her students was a significant obstacle to her teaching effectiveness, it was clear that the experience raised her awareness of the relationship between language and culture and her conviction that needs assessment is critical to effective teaching. As in the case of Mariko, Sachiko's placement may have exacerbated her personal teaching concerns since the fact that her students were adults who had lived in the U.S. longer than she meant that they knew more than she did about U.S. culture. Believing that the teacher should be the knower, she was convinced she had done an inadequate job teaching. 
Sadayuki: "I like innovative ways to teach."

Unlike Mariko and Sachiko, Sadayuki had had no previous teaching experience in Japan, although he had recently passed the exam to get a teaching credential and had a job teaching high school English when he returned to Japan. He was the youngest of the focus students and had spent less time in an English-speaking country than any of the other students. In light of these factors, one might have anticipated that he would have had the most difficulty in coping with the many challenges of being an ESL teacher. However, my observations of his classes, as well as his own reflections on his teaching, suggested otherwise.

Sadayuki chose to work in a credit-bearing community college reading course. His pupils were the most proficient of all of the students' pupils, except for Mariko, who, as mentioned earlier, was very nervous about her own competency in teaching such high level students. Although Sadayuki did express some reservations about his competency in English, he was much more concerned about how he could design lessons that he believed were innovative. As he put it in his final report. "I like innovative ways to teach. So, I want to keep in mind that my teaching style in the future will be very different from that of today." (FR, page 3, 12-11-98)

He was fortunate to work with a mentor teacher who encouraged him to experiment with new ways of presenting materials to students and provided him with a great deal of feedback on his teaching, which he took very seriously. In trying to use new activities, his mentor teacher pointed out that he often spent too much time explaining the directions. In fact, as his mentor teacher pointed out it in her log, "The instructions were often so detailed that he even forgot to tell the students some important aspects of the tasks because he gave more attention to the smaller details" (ML, page 1, 12-5-98). Sadayuki took this feedback very seriously and experimented with different ways of giving directions. In his final report, he reflected on his own progress in learning to give directions.

I tried several ways to give directions. I used models about activity, oral explanations, printed handout, written explanations on the board. I was also careful with the timing to give Ss handouts since if I gave them handouts at the beginning of the activities, Ss would pay attention to the handout and never listen to me.

Still now, I haven't come up with the "best" way to give Ss directions. (FR, page 3, 12-7-98)

In one of our post-lesson interviews, Sadayuki and I talked about his struggle to find out the best way to give directions to a class. 
Sadayuki talked about how he had to acquire the metacognitive strategies of giving directions in English in a western culture. He pointed out that models of activities were rarely used in Japanese classrooms when giving directions. (FN, page 1, 10-30-98)

As mentioned earlier, because of the focus in their graduate program on communicative language teaching and student-centered group activities, the students were concerned with implementing group activities in their practicum experience. Sadayuki, perhaps more than any of the other students, tried to implement group activities in his class. In describing his own work in adapting materials in the textbook, he wrote:

I tried to have as many different kinds of activities as possible throughout the course. Most of the activities were group activities. I received the different kinds of reactions about group activities, especially about the 1 st group activity that I did which is called "Literature Circles" mentioned in my third log. I gave the evaluation sheet on Literature Circles. Some students gave me very positive comments on group work in which each $\mathrm{S}$ had his or her own role. ... But a few of the Ss commented that the group activity was not helpful.... One reason about the negative feedback on the group work in general is, I assume, because of Ss' educational background. Since many Ss in this course might have been accustomed to the teacher-centered style or might feel secure because of their language proficiency if the class is teacher-centered and there is fewer opportunities to talk, they may not prefer group work as a learning process. Another reason might be that my explaining about the rationale of the group activity to SS was not clear ...

In conclusion what I learned was it might be helpful for me to assess the Ss' preference about learning styles. . . . I am sure I will use some assessment procedures for my future teaching at a Japanese high school though I can predict now that they will prefer teacher-centered instruction. But I may be able to change the class atmosphere into more student-centered little by little, not all of a sudden. (FR, page 2$3,12-11-98)$

This entry was typical of Sadayuki's general approach to teaching. He liked to experiment with new ways of teaching, but he was equally concerned with carefully assessing how successful the activity had been. In addition, he was fully aware of the fact that what was successful in a U.S. context may not be successful in a Japanese context. Indeed, he was the one in the group interview who half jokingly pointed out that he would probably have to wait five years on his new job before trying to implement significant changes in classroom methodology. 


\section{Conclusion}

\section{The Practicum Course}

As a regular course supervisor for the practicum experience of a MA TESOL program this examination of Japanese teacher trainees' reflections on their practicum experience has raised my awareness of the need for change in several areas of the practicum course. First, more counseling needs to be implemented in the placement of teacher trainees in their practicum, particularly for nonnative speakers. Whereas many teacher trainees are aware of their lack of knowledge of English, being a nonnative speaker of English can make this concern paramount, particularly as it relates to cultural knowledge. One might argue that placing nonnative teacher trainees in more advanced level ESL classes could exacerbate this concern. However, as is evident from the issues raised by Sadayuki's reflections, some teacher trainees placed in advanced classes are less concerned with their lack of knowledge than with other issues of being an effective teacher. Hence, more extensive interviews with teacher trainees and their teaching concerns may help practicum supervisors counsel teacher trainees to select a context that would be most beneficial to their development as teachers.

Second, to the extent that practicum experiences encourage teacher trainees to undertake reflections on their teaching experience, it is important that the experience include mechanisms for bringing teacher trainees from what Stanley (1998) terms engaging in reflection to practicing reflection so that teachers apply the insights they have gained through reflection to their own teaching context. Although this can be done and often is done in practicum supervisors' conferences with teacher trainees, additional ways of helping teacher trainees modify their teaching actions based on their teaching reflections might be incorporated throughout the program. Stoynoff (1999), for example, describes how the practicum experience at his university is integrated into the academic program for the entire 12 months of the program, involving the active participation of mentor teachers, graduate program faculty advisors, language institute administrators, and the teacher trainees themselves. Although such a practicum involves greater costs and coordination, Stoynoff contends that such a model "offers students an integrated, developmental experience that acknowledges the long-term process of learning to teach and becoming members of a profession" (p. 150). Implementing a long-term integrated approach to the practicum would allow teacher trainees to examine their teaching reflections within the context of their academic program. Hence, for example, if the practicum experience had been integrated throughout the graduate pro- 
gram, the teacher trainees' specific concern with the methodology implemented by their mentor teachers as well as their concern for its appropriateness in a Japanese context could have been raised in the context of their methods courses.

\section{The Japanese Native Speaker as a Teacher Trainee in an ESL Context}

The difficulties these five Japanese teacher trainees encountered in their practicum may seem to suggest that there are few benefits for Japanese graduate teacher trainees to have an ESL teaching experience. There are, however, several benefits these teacher trainees did gain from the experience. First, even though several of the teacher trainees such as Mariko and Sachiko expressed a lack of knowledge about English grammar and vocabulary, their struggle with these facets of English served to increase their knowledge of English. Whereas Sachiko was not originally familiar with the differences between such words as "clinic" and "hospital," or "day-care center" and "nursery school" in the U.S. context, her practicum experience provided her with this information. Even more importantly, this experience highlighted for Sachiko the fact that the meaning of lexical items is embedded in the cultural context of their use. As such, her language expertise, in Rampton's (1990) sense, was increased. In addition, the teacher trainees were developing one important attribute of a native speaker, an attribute highlighted by Medgyes (1992; 1994), namely the ability to provide their students with more cultural information surrounding the use of English.

Secondly, experiences such as Koji's uncertainty as to whether or not ESL students need a focus on accuracy or Sachiko's questioning of whether or not ESL students should learn to talk about jobs because this was an acceptable U.S. classroom topic served to raise the teacher trainees' awareness that student needs and appropriate classroom topics may differ cross-culturally. Finally, because of the contrasts the teacher trainees experienced between a largely teacher-centered Japanese English classroom and more student-centered U.S. classrooms, the teacher trainees were forced to consider the advantages and disadvantages of each and their appropriateness for different contexts. In the process of examining these two types of classrooms, not only were they increasing their repertoire of teaching approaches, but they were also learning to assess these approaches in light of specific teaching contexts.

Perhaps the most difficult challenge confronting these five teacher trainees is the one they may face as they return to Japan and their English teaching careers. The expertise they have gained in their graduate program in terms of linguistic knowledge and teaching methods may not be valued and perhaps may even be viewed by some as a 
threat. On the other hand, hopefully their increased awareness of how language and teaching methods are socially and culturally bound will help them apply their new expertise in ways that are highly productive for English teaching in the Japanese context.

\section{Acknowledgments}

I would like to thank my five Japanese graduate students who so willingly and perceptively shared with me their reactions to their ESL practicum experience. I also thank the mentor teachers for sharing with me their reactions to the students' teaching experience and Shimako Iwasaki for her careful job in transcribing the group interview.

Sandra McKay is Professor of English at San Francisco State University where she teaches in the MA TESOL program. Her research interests include second language literacy and macro-sociolinguistics.

\section{Notes}

1. For a recent description of two practicum experiences, one in the EFL and the other in an ESL context, see Flowerdew, 1999 and Stoynoff, 1999.

2. However, see Johnson 1996 for a report on a case study of one teacher trainee's practicum experience.

3. All names are pseudonyms.

4. All excerpts are marked with the source of the data, the page number, and the date. The following abbreviations are used with the data.

TL - the students' teaching logs

$\mathrm{BQ}$ - the students' language and teaching background questionnaire

FR - the students' final report

GI - transcripts of the group interview

FN - the author's field notes

ML - the mentor teachers' logs

5. The following symbols have been used in the transcripts:

... : trailing off / pause

*: unintelligible speech

?: question / rising contour

6. I am grateful to one of the JALT Journal reviewers for pointing out this possibility.

\section{References}

Flowerdew, J. (1999). The practicum in L2 teacher education: A Hong Kong case study. TESOL Quarterly, 33(1), 141-145.

Johnson, K. E. (1996). The vision versus the reality: The tensions of the TESOL practicum. In D. Freeman \& J. C. Richards (Eds.), Teacher learning in language teaching (pp. 30-49). New York: Cambridge University Press.

Kornblum, H. (1992). Directory of professional preparation programs in TESOL in the United States. Alexandria, VA: TESOL.

Liu, J. (1999). Nonnative English-speaking professionals in TESOL. TESOL Quar- 
terly, 33(1).

Medgyes, P. (1992). Native or non-native: Who's worth more? ELT Journal, 46(4), 340-349.

Medgyes, P. (1994). The non-native teacher. London: Macmillan Publishers Ltd. Palmer, I. C. (1995). Required courses for master's degrees: A nationwide survey. Paper presented at the 29th Annual TESOL Convention. Long Beach, CA.

Rampton, M. B. H. (1990). Displacing the 'native speaker': Expertise, affiliation, and inheritance. ELT Journal, 44(2), 97-101.

Richards, J. C. (1990). The language teaching matrix. New York: Cambridge University Press.

Richards, J. C., \& Crookes, G. (1988). The practicum in TESOL. TESOL Quarterly, 22(1), 9-27.

Stanley, C. (1998). A framework for teacher reflectivity. TESOL Quarterly, 32(3), 584-591.

Stoynoff, S. (1999). The TESOL practicum: An integrated model in the U.S. TESOL Quarterly, 33(1), 145-151.

Valli, I. (1992). Reflective teacher education: Cases and critiques. Albany: SUNY Press.

Wallace, M. (1996). Structured reflection: The role of the professional project in training ESL teachers. In D. Freeman \& J. C. Richards (Eds.), Teacher learning in language teaching (pp. 281-290). New York: Cambridge University Press.

(Received February 1, 1999; revised May 7, 1999) 